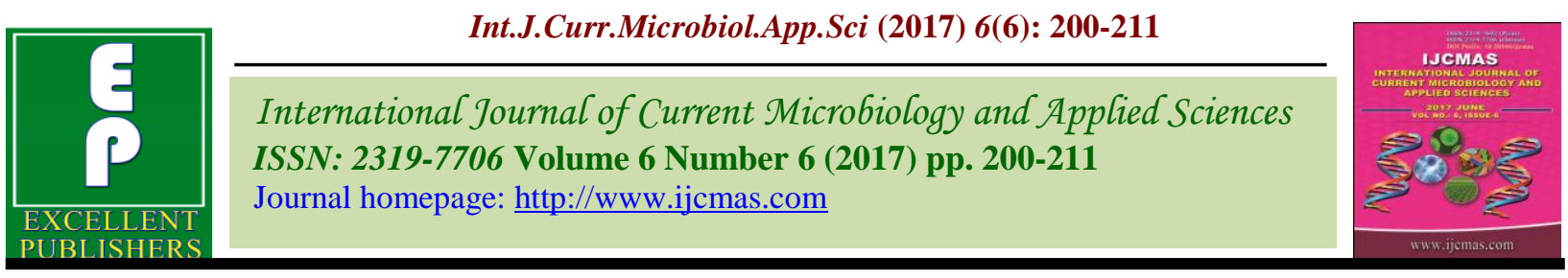

Original Research Article

https://doi.org/10.20546/ijcmas.2017.606.024

\title{
Microbial Contamination of Mobile Phones in the Medical Laboratory Technology Department of a Private University in Alexandria, Egypt
}

\author{
Hadir EL-Kady* \\ Department of Medical Laboratory Technology, Faculty of Allied Medical Sciences, \\ Pharos University, Alexandria, Egypt \\ *Corresponding author
}

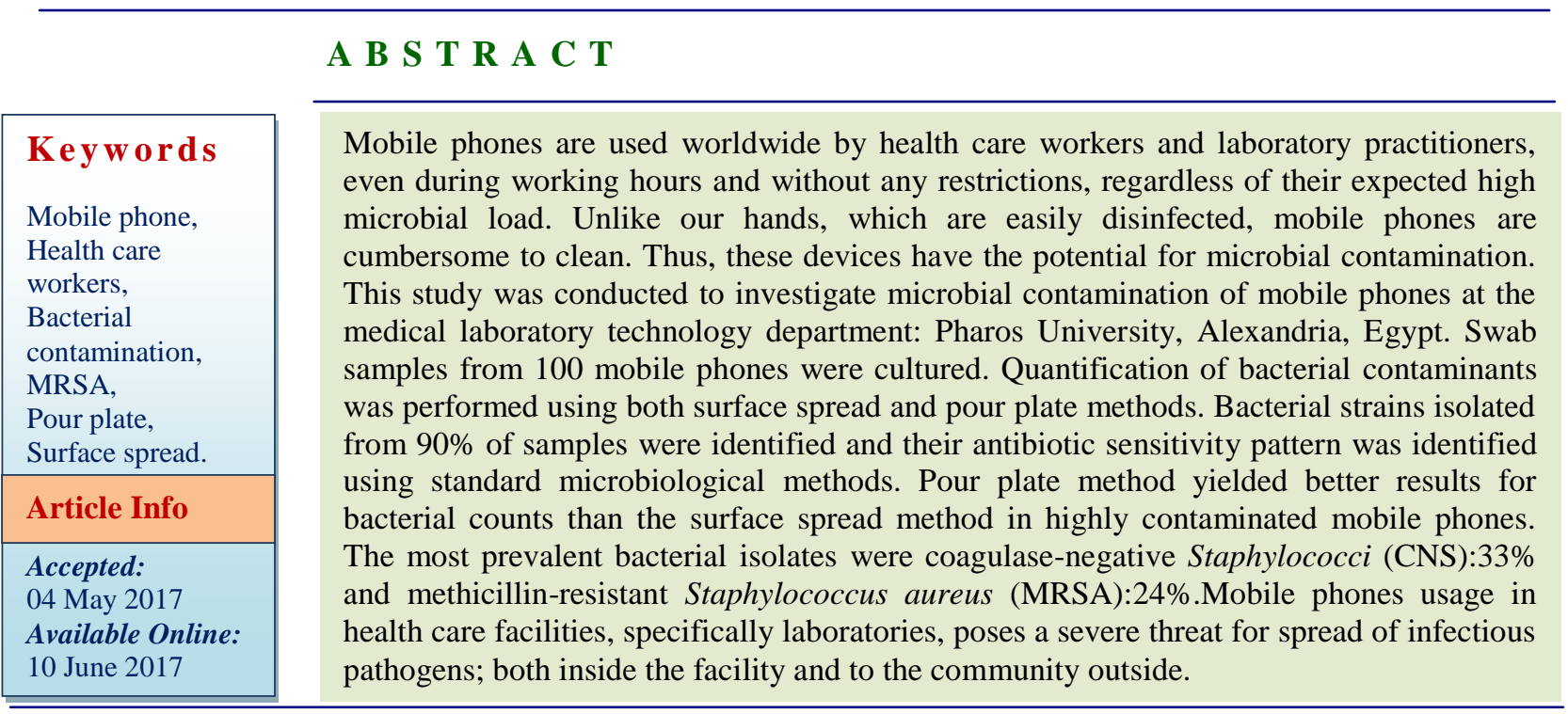

\section{Introduction}

Mobile phones have become integral and indispensable accessories of professional and social daily life. They are increasingly becoming an important means of conversation worldwide; being easily accessible, economical and user friendly (Selim and Abaza, 2015).

Approximately $75 \%$ of adults worldwide have access to mobile phones. Three-quarters of the world's seven billion mobile phone subscribers live in low- and middle- income countries, making the developing world more mobile than the developed world (Kamiset al., 2015).
With all the achievements and benefits of the mobile phone, it is possible to overlook the health hazards it might pose to its many users(Czapiński and Panek,2011).As it can easily fit in one's pocket, mobile phones have become part of the so-called emotional technology, used frequently even in environments of high bacteria presence as health care facilities.

In medical laboratories, mobile phones are often touched during activities related to sample collection, sample processing, culturing of microorganisms, etc. Therefore, mobile phones are likely to get contaminated 
by various micro-organisms, some of which could be pathogenic in nature and multiple drug-resistant at times (Jaya Madhuri et al., 2015).

Frequency of microbial contamination of mobile phones used by health care workers (HCWs) ranges from $20 \%$ to $100 \%$, as recorded by several investigators (Goldblatt et al.,2007; Bobat et al., 2016; Deshkar et al., 2016; Ramesh et al., 2008; Lavanya et al., 2016; Chaka et al., 2016; Ananthakrishnan et al., 2006; Amer et al., 2016; Chawla et al., 2009; Tambe and Pai, 2012; Tiwari et al., 2016; Karthiga and Muralidaharan, 2016; Elkholy and Ewees, 2010; Ustun and Cihangiroglu, 2012; Selim and Abaza, 2015).

Drug resistant pathogens such as methicillinresistant Staphylococcus aureus (MRSA) and vancomycin resistant Enterococci (VRE) have been recovered from many of these mobile phones; raising important safety concerns about the use of such devices in health care facilities (Mark et al., 2015). There are no specific mandatory guidelines for disinfection of mobile phones that meet hospital and laboratory standards. Moreover, mobile phones besides being used routinely all day long; including work hours, yet the same phones are still used both inside and outside the health care facilities. Accordingly, mobile phones act as a vector spreading pathogenic microorganisms to different parts of the health care facility and out of it as well (Parhizgari et al., 2013).

The average user of a mobile phone touches its screen around one hundred and fifty times a day causing the frequent migration of bacteria from the mobile phone to the skin and vice versa (Jeske et al., 2007). Mobile phones are also placed on numerous surfaces, countless number of times each day; which causes the microorganisms to migrate from such surfaces that the phone had contact with to the phone itself (Akinyemi et al.,2009).
The constant handling of mobile phones by users (multiple users in some cases) in health care facilities makes it an open breeding place for transmission of microorganisms, especially those associated with the skin due to the moisture and optimum temperature of human body especially the palms. Mobile phones are the reservoir of pathogens as they touch face, ears, lips and hands of different users of different health conditions (Goeland Goel, 2009). Keeping the mobile phones in the pockets, handbags and snug pouches increases the possibility of bacterial proliferation. Warmth, ideal temperature conditions and heat generated by mobile phones contribute to harboring bacterial populations on such devices at alarming rates (Jaya Madhuri et al., 2015; Tagoe et al., 2011).

Despite being used on a continuous basis, these mobile phones are seldom cleaned and the problem is again aggravated by the fact that many mobile phone users do not have regard for their personal hygiene specially that related to their use of such devices (Jaya Madhuri et al., 2015).

This study was conducted to investigate the bacterial contamination of mobile phones among a group of paramedical university students, staff members and laboratory specialists at the medical laboratory technology department, Faculty of Allied Medical Sciences: Pharos University in Alexandria (PUA), Egypt and also to compare the results of Surface Spread technique (SS) versus those of Pour Plate technique (PP) in determining the bacterial count on the tested mobile phones.

\section{Materials and Methods}

\section{Study design, samplesize and study setting}

This cross-sectional study was conducted over a period of 3 months (February to April 
2016). The mobile phones of randomly selected 100 paramedical students, staff members and laboratory specialists at the Medical Laboratory Technology Department of the Faculty of Allied Medical Sciences: (PUA), were tested for bacterial contamination.

An oral informed consent was obtained from all the enrolled volunteers. A selfadministered questionnaire covering demographic data and data about use of mobile phone and hygiene related to its use was filled in by each participant.

\section{Samples collection and processing}

Samples from mobile phones were aseptically collected using sterile cotton swabs. Each swab, moistened with sterile peptone water was rotated over the screen, keys, mouthpiece, earpiece and back-panel of the mobile, together with the keypad in nontouchscreen phones. All swabs were immediately streakedby (SS) method over the surface of blood and Mac Conkey's agar plates. The cotton end of each swab wasthen cut off and soaked in $10 \mathrm{ml}$ peptone water. Blood and Mac Conkey's agar plates were incubated aerobically at $37^{\circ} \mathrm{C}$ for 24 hours.

The inoculated peptone water tubes were vortexed and one $\mathrm{ml}$ from each tube was transferred to the center of a sterile petri dish, then $15 \mathrm{ml}$ of molten plate count agar medium was poured over the sample portion. The agar was thoroughly mixed with the sample portion and allowed to set and solidify. The plates were then inverted and incubated aerobically at $37^{\circ} \mathrm{C}$ for 24 hours.

\section{Quantification of bacterial isolates}

Isolated colonies on blood and Mac Conkey's agar plates using (SS) method were counted and recorded as number of organisms/phone.
The number of colony forming units (CFU) for each sample tested by (PP) method was then counted using the Quebec colony counter and recorded as CFU/ml.

\section{Identification of isolates}

Bacterial isolates on blood and Mac Conkey's agar plates were tested for colony morphology, Gram stained, examined microscopically and accordingly were tested biochemically according to the standard microbiological methods described by Forbes et al., (2007).

For identification of Gram-positive cocci (GPC); isolates that appeared as medium sized, circular, white or golden yellow with smooth convex surface and entire edge, were $\beta$-hemolytic or non-hemolytic on blood agar and were positive for catalase, slide and tube coagulase tests and for Voges Proskauer (VP) test were considered as Staphylococcus aureus (S. aureus). Catalase positive, coagulase-negative and bacitracin-resistant GPC were considered as Coagulase-negative Staphylococci (CNS). Non-haemolytic, catalase-positive, coagulase-negative, bacitracin-sensitive GPC were identified as Micrococcus spp.

As regards Gram-negative bacilli (lactose and non-lactose fermenters), they were tested for oxidase production and for a set of biochemical reactions using API 20 E (Biomerieux).

The antibiotic sensitivity pattern of all isolates was detected using the disc agar diffusion procedure: Modified Kirby-Bauer antibiotic sensitivity test (Bauer et al., 1966). The inhibition zone diameters were measured and interpreted as recommended by the Clinical and Laboratory Standards Institute (CLSI) (Wayne, 2014). S. aureus isolates were further checked for their susceptibility to 
methicillin using oxacillin $(1 \mu \mathrm{g})$ and cefoxitin $(30 \mu \mathrm{g})$ discs on Mueller Hinton agar plates supplemented by $4 \% \mathrm{Na} \mathrm{Cl}$.

Gram negative isolates were further tested for being extended spectrum beta-lactamase (ESBL) producers using the double disk diffusion method according to CLSI recommendations. Ceftazidime $30 \mu \mathrm{g}$, ceftazidime-clavulanate $30 / 10 \mu \mathrm{g}$, cefotaxime $30 \mu \mathrm{g}$ and cefotaxime-clavulanate $30 / 10 \mu \mathrm{g}$ discs were used. $A \geq 5 \mathrm{~mm}$ increase in a zone diameter for either antimicrobial agent tested in combination with clavulanate versus the zone diameter of the agent when tested alone confirmed ESBL producers.

\section{Statistical analysis}

Statistical analysis was carried outby using SPSS version 16 (Dniel, 2009). The significance level (0.05 parametric) was used to indicate statistical significance.

\section{Results and Discussion}

In the past few years, the mobile phone gradually became more and more involved in our daily life, including its private and workrelated capacities. With high level of mobile phone penetration, a mobile culture has evolved, where the phone has become a key social tool. High technology applied in mobile phones has led to a better strategic life with good communication (Akinyemi et al., 2009).

In an attempt to provide better communication and health care facilities, nowadays nearly $100 \%$ of HCWs own and use mobile phones. In fact, uncontrolled use of mobile phones by HCWs increases the spread of nosocomial infections (Amer et al., 2016). Actually, not all HCWs clean their hands before or after using their phones which exposes both themselves as well as the others to the risk of transferring infections. $\mathrm{HCW}$ scan transfer microorganisms from the patient himself or from one of the samples taken from him to their own hands, from their hands to their phones, and from their phones to their faces, mouths and ears. In reverse, HCW scan transfer microorganisms from their phones to patients or to other members of the community outside the health care facility (Bobat et al., 2016).

The publicly-expressed worries about using a device harboring microbial contaminants have urged the performance of several related research projects worldwide. Variable contamination rates of cell phones were reported in different countries: USA: $20 \%$ (Goldlatt et al.,2007), UK: 55 \% (Brady et al.,2012), Nigeria and Ethiopia: $62 \%$ each (Akinyemi et al., 2009, Tolossa et al., 2016), India: $72.5 \%$ (Ananthakrishnan and Gunasekaran, 2006), Australia: $74 \%$ (Chao Foong et al.,2015), KSA: $84 \%$ (Vinod Kumar et al.,2014), Turkey: 94.5\% (Ulger et al.,2009), Austria: 95\% (Jeskeet al.,2007) and Cairo: 96.5\% (Elkholy and Ewees, 2010). This variation may be due to differences in mobile phone handling and cleaning and in hand washing practice.

The present work enrolled 100 mobile phones that were randomly selected according to the available volunteers on the days of sampling. The mobile phones belonged to 78 students (78 \%), 13 staff members (13\%) and 9 laboratory specialists $(9 \%)$ at the Medical Laboratory Technology Department of Faculty of Allied Medical Sciences at PUA. The majority $(80 \%)$ of mobile phones were touch screen mobiles while only $20 \%$ were keypad mobiles. Only 38\% of mobile phones were old ( $\geq$ one year) compared to $62 \%$ of which that were new mobile phones. As regards covers; most of the mobile phones examined $(78 \%)$ were not kept in covers while only $22 \%$ of which was kept in covers.

The current results revealed that the majority (90\%) of the tested mobile phones were 
contaminated with bacterial isolates compared to only $10 \%$; out of which no bacteria was recovered. All the ten sterile mobile phones belonged to paramedical students. No statistically significant difference was found in the rate of bacterial contamination of tested mobile phones based on gender, occupation or frequency of use of mobile phones by their owners.

Nearly similar results were reported by Tiwari et al., (2016), Brady et al., (2006) and Jeske et al., (2007), who reported contamination rates of $88.13 \%, 89.7 \%$ and $90 \%$, respectively, in the mobile phones they examined.

Higher rates of mobile phone contamination $(>90 \%)$ have been also reported, worldwide, by several investigators (Deshkar et al., 2016; Tiwari et al., 2016, Karthiga and Muralidharan, 2016; Elkholy and Ewees, 2010; Ustun and Cihangiroglu, 2012). Furthermore, a contamination rate of $100 \%$ was reported recently in Alexandria by Selim and Abaza (2015). On the other hand, lower contamination rates ranging from as low as 17 $\%$ (Al-Mudares et al., 2012) to as high as 83\% (Tambe and Pai, 2012; Shakir et al., 2015) have also been reported.

In the present work, a single isolate was detected in $64 \%$ of tested mobile phones while more than one type of isolates was detected in only $26 \%$ of which. On the other hand, polymicrobial growth was observed in $100 \%$ of mobile phones examined by Selim and Abaza (2015) and Tagoe et al., (2011). Also, Srikanth et al., (2010), Chawla et al., (2009) and Ulger et al., (2009) reported polymicrobial growth in $71 \%, 67.5 \%$ and 46 $\%$, respectively of $\mathrm{HCW}$ mobile phones.

The present results highlighted that $66 \%$ of the participants cleaned their mobile phones frequently compared to $34 \%$ who claimed they never cleaned their phones. The rates of frequent cleaning of HCWs, mobile phones recorded worldwide in previous studies varied from $10.5 \%$ in Turkey (Ulger et al., 2009) to $31 \%$ in Australia (Shaker et al., 2015). In the gulf zone, $66.5 \%$ of HCWs in Kuwait (Heyba et al., 2015) and 76\% of those in KSA stated they never cleaned their mobile phones (Sadat-Ali et al., 2010).

Table 1 illustrates that out of the 66 cell phones which were recorded to be cleaned by their owners in the current study, 54 (81.8\%) yielded only one type of organism while 24 $(70.6 \%)$ of the 34 cell phones which were never cleaned by their owners yielded more than one type of organisms. The difference between these results was found to be highly statistically significant ( $p$-value $<0.001$ ).

It has been also noted that the majority (73\%) of individuals enrolled in the present study reported that they never perform any hand hygiene practices in relation to the use of their mobile phones. Out of the mobile phones of those 73 participants, $47(64.4 \%)$ grew only one type of organisms compared to $63 \%$ (17/27) of those who practiced hand hygiene practices. There was no statistical significant difference between the two groups (Pvalue $=0.587$ )

\section{Estimation of the bacterial load on mobile phones}

In the current research bacterial count on mobile phones was determined by two techniques simultaneously: PP and SS methods. It can be seen in table 2 that a mean bacterial count of $653.73 \mathrm{CFU} / \mathrm{ml}$ and a median of $250 \mathrm{CFU} / \mathrm{ml}$ were recorded by the PP method while the corresponding figures were 305.71 and 137.50 organisms/phone using the SS method. There was a statistically significant difference between the two methods ( $\mathrm{p}$-value $<0.001$ ). The current results 
showed that PP method yields much higher number of isolates than SS method in count categories of $\geq 100 \mathrm{CFU} /$ phone (mean of 1066.33 and 535.51, respectively). This was found to be statistically significant ( $\mathrm{p}$-value < 0.001). On the other hand, there was no statistical significant difference between the two methods regarding the lower count categories of $<10$ and $10-<100 \mathrm{CFU} /$ phone (Table 3).

This finding was contradictory to that reported by Selim and Abaza, 2015, who stated that in low and moderate bacterial counts $(<10$ and $\geq 10$, respectively), SS method yielded statistically significant higher numbers of organisms than PP method, while in high counts $(\geq 100)$, though SS method revealed higher numbers of isolates than those yielded by PP method, yet this was not found to be statistically significant. Thus, they recommended SS method as an easier and less laborious technique of bacterial count compared to PP method.

Table.1 Relationship between the count of bacterial isolates on tested mobile phones and different parameters related to their owners: gender, occupation, frequency of use of mobile, mobile cleanliness and hand hygiene practices

\begin{tabular}{|c|c|c|c|c|c|c|c|c|c|c|c|c|c|}
\hline & \multicolumn{6}{|c|}{$\begin{array}{c}\text { Number of bacterial agents } \\
\text { isolated }\end{array}$} & \multirow{2}{*}{\multicolumn{2}{|c|}{ Total }} & \multirow{3}{*}{ Mean } & \multirow{3}{*}{ SD. } & \multirow{3}{*}{ Median } & \multirow{3}{*}{$\chi^{2}$} & \multirow{3}{*}{ p-value } \\
\hline & \multicolumn{2}{|c|}{$\begin{array}{c}\text { No } \\
\text { isolates }\end{array}$} & \multicolumn{2}{|c|}{$\begin{array}{c}\text { One type } \\
\text { of } \\
\text { organisms }\end{array}$} & \multicolumn{2}{|c|}{\begin{tabular}{|l|}
$>1$ type of \\
organisms
\end{tabular}} & & & & & & & \\
\hline & No. & $\%$ & No. & $\%$ & No. & $\%$ & No. & $\%$ & & & & & \\
\hline Gender & & & & & & & & & & & & & \\
\hline Male & 4 & 9.8 & 25 & 61.0 & 12 & 29.3 & 41 & 100.0 & 1.20 & 0.60 & 1.0 & & \\
\hline Female & 6 & 10.2 & 39 & 66.1 & 14 & 23.7 & 59 & 100.0 & 1.14 & 0.57 & 1.0 & 0.389 & 0.823 \\
\hline Occupation & & & & & & & & & & & & & \\
\hline Student & 10 & 12.8 & 47 & 60.3 & 21 & 26.9 & 78 & 100.0 & 1.14 & 0.62 & 1.0 & & \\
\hline Staff & 0 & 0.0 & 11 & 84.6 & 2 & 15.4 & 13 & 100.0 & 1.15 & 0.38 & 1.0 & 3.379 & \\
\hline Laboratory Specialist & 0 & 0.0 & 6 & 66.7 & 3 & 33.3 & 9 & 100.0 & 1.33 & 0.50 & 1.0 & & \\
\hline $\begin{array}{l}\text { Frequency of use of } \\
\text { mobile }\end{array}$ & & & & & & & & & & & & & \\
\hline$\leq 5$ times/day & 1 & 12.5 & 5 & 62.5 & 2 & 25.0 & 8 & 100.0 & 1.13 & 0.64 & 1.0 & 0460 & ${ }^{M C} \mathrm{p}_{\mathrm{p}}$ \\
\hline $6-50$ times/day & 9 & 9.8 & 59 & 64.1 & 24 & 26.1 & 92 & 100.0 & 1.16 & 0.58 & 1.0 & 0.400 & 1.000 \\
\hline Cleaning of mobile & & & & & & & & & & & & & \\
\hline Yes & 10 & 15.2 & 54 & 81.8 & 2 & 3.0 & 66 & 100.0 & 1.16 & 0.60 & 1.0 & 54.17 & \\
\hline Never & 0 & 0.0 & 10 & 29.4 & 24 & 70.6 & 34 & 100.0 & 1.16 & 0.55 & 1.0 & $3^{*}$ & $<0.001$ \\
\hline $\begin{array}{l}\text { Hand wash and } \\
\text { disinfection in relation } \\
\text { to use of mobile }\end{array}$ & & & & & & & & & & & & & \\
\hline Yes & 4 & 14.8 & 17 & 63.0 & 6 & 22.2 & 27 & 100.0 & 1.07 & 0.62 & 1.0 & 1067 & 0.587 \\
\hline Never & 6 & 8.2 & 47 & 64.4 & 20 & 27.4 & 73 & 100.0 & 1.19 & 0.57 & 1.0 & $1.00 /$ & 0.581 \\
\hline Total & 10 & 10.0 & 64 & 64.0 & 26 & 26.0 & 100 & 100.0 & & & & & \\
\hline
\end{tabular}

$\chi^{2}$ : Chi square test $*$ statistically significant at $\mathrm{p} \leq 0.05 \mathrm{MC}$ : Monte Carlo for chi square test $* *$ statistically significant at $\mathrm{p} \leq 0.01$ 
Table.2 Descriptive analysis of the positive examined mobile phones according to their bacterial load counted by PP and SS techniques

\begin{tabular}{||l|c|c|c|c||}
\hline & Min. - Max. & Mean \pm SD. & Median & $\begin{array}{c}\text { p- } \\
\text { Value }\end{array}$ \\
\hline SS method & $2.0-2500.0$ & $305.71 \pm 414.59$ & 137.50 & \multirow{2}{*}{$<0.001^{*}$} \\
\hline PP method & $6.0-3200.0$ & $653.73 \pm 861.62$ & 250.0 & \\
\hline
\end{tabular}

Table.3 The count of bacterial isolates contaminating the 100 tested mobile phones using SS and PP techniques

\begin{tabular}{|c|c|c|c|c|c|c|c|c|c|}
\hline \multirow{2}{*}{$\begin{array}{l}\text { Count } \\
\text { categories }\end{array}$} & \multicolumn{4}{|c|}{$\begin{array}{c}\text { Count by SS method (organism/mobile } \\
\text { phone) }\end{array}$} & \multicolumn{4}{|c|}{ Count by PP method (CFU/ml) } & \multirow{2}{*}{$\begin{array}{c}\text { p- } \\
\text { Value }\end{array}$} \\
\hline & Mean & SD. & Median & $\begin{array}{c}\text { Geometric } \\
\text { mean }\end{array}$ & Mean & SD. & Median & $\underset{\text { mean }}{\text { Geometric }}$ & \\
\hline$<10$ & 4.86 & 2.04 & 6.0 & 4.37 & 6.67 & 0.58 & 7.0 & 6.65 & 0.181 \\
\hline $\begin{array}{l}10- \\
<100\end{array}$ & 36.47 & 24.73 & 31.0 & 28.53 & 37.39 & 19.77 & 32.0 & 31.98 & 0.867 \\
\hline$\geq 100$ & 535.51 & 447.02 & 447.0 & 400.86 & 1066.33 & 901.53 & 725.0 & 713.81 & $<\underset{*}{0.001}$ \\
\hline Total & 305.71 & 414.59 & 137.50 & 103.93 & 653.73 & 861.62 & 250.0 & 195.60 & \\
\hline
\end{tabular}

$\mathrm{P}: \mathrm{p}$ value for Student $\mathrm{t}$-test $*$ : Statistically significant at $\mathrm{p} \leq 0.05$

Table.4 Types of Isolates in the 100 Studied Mobile Phones

\begin{tabular}{|l|c|c|}
\hline Names of identified isolates & No. & $\%$ \\
\hline - CNS & 33 & 33.0 \\
- S. aureus & 24 & 24.0 \\
- Micrococci & 17 & 17.0 \\
- E. coli & 15 & 15.0 \\
- Viridans Streptococci & 11 & 11.0 \\
- Diphtheroids & 9 & 9.0 \\
- Klebsiella pneumoniae & 5 & 5.0 \\
- Enterobacter aerogenes & 2 & 2.0 \\
\hline
\end{tabular}

*S. aureus isolates: 21 out of $24(87.5 \%)$ were MRSA and only 3 (12.5\%) were MSSA

* All Klebsiella pneumoniae isolates (100\%) were ESBL strains. 
Fig.1 Distribution of the isolated bacteria according to their antibiotic sensitivity patterns $(\mathrm{n}=116$ isolates $)$

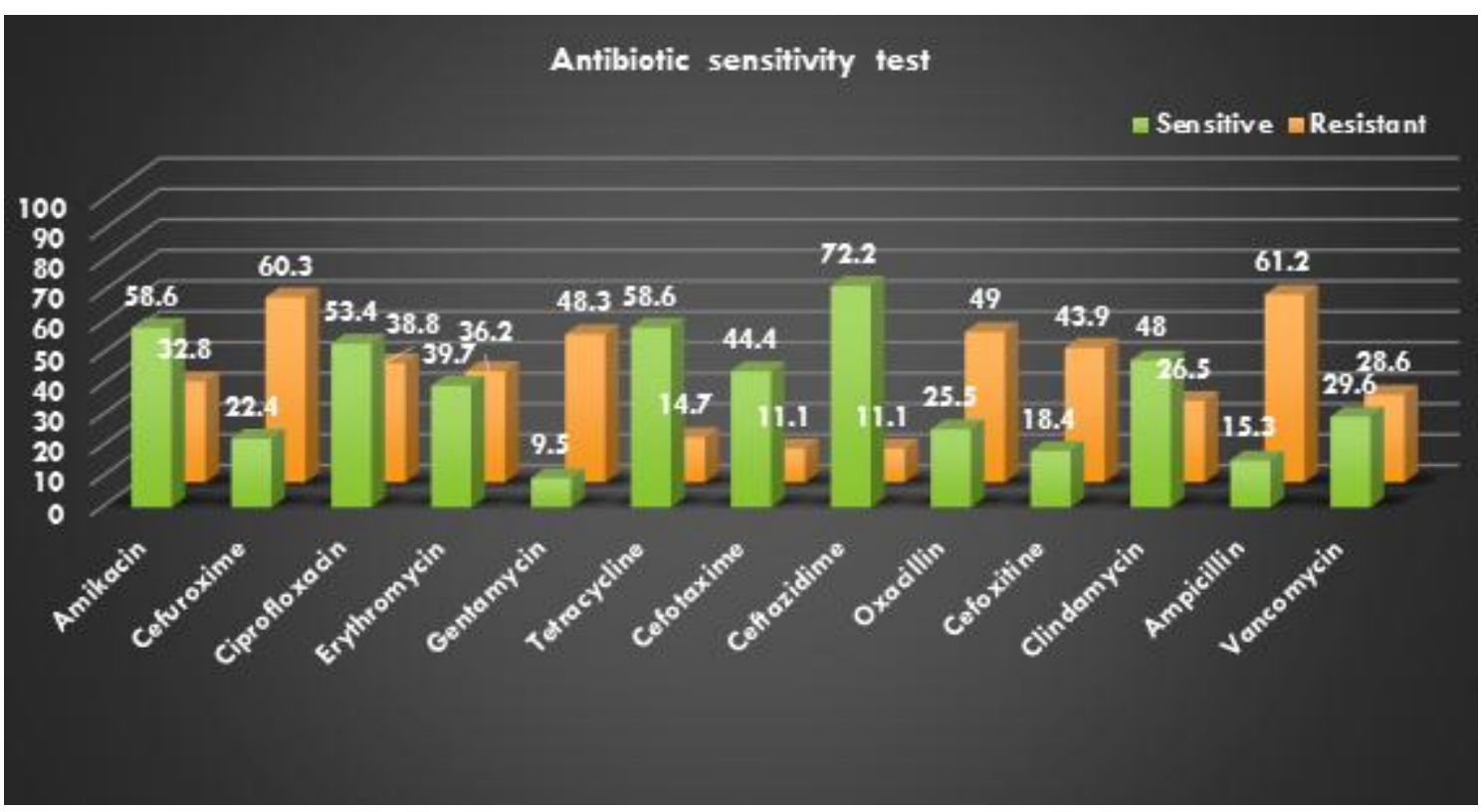

Previous results by Tagoe et al., (2011), showed much higher levels of bacterial contamination of mobile phones used by students in the University of Cape Coast with an overall mean viable bacterial count of $9.9 \times 105$ CFU using PP method. This could be attributed to difference in the level of hand hygiene practice in relation to the use of mobile phones. In general; the greater the concentration of the microbe, the longer it survives and survival can range from minutes to months.

On the other hand, in a previous study by $\mathrm{Pal}$ et al., (2013), the median colony count for touch screen phones and keypad devices was as low as $0.09 \mathrm{CFU}$ and $0.77 \mathrm{CFU}$, respectively.

High contamination rates of mobile phones of HCWs could be attributed to several factors as: infrequent cleaning of mobile phones during working hours, low compliance of hand washing and unawareness of the fact that mobile phones can also act as a vector for transmission of pathogenic organisms. As per the instructions of mobile phone manufacturers that emphasize that contact with water or liquid disinfectant might damage the software of mobile phones, even most of them who are aware of its pathogenic potential also don't clean their phones. Currently in many institutions, strict guidelines have not been implemented to restrict medical staff from carrying mobile phones into the work zones and there are also no cleaning guidelines for mobile phones of HCWs.

\section{Bacteria isolated from contaminated mobile phones}

It is clear from table 4 that the most common isolate in the present study was CNS detected in $33 \%$ of cases followed by S. aureus $(24 \%)$; $87.5 \%$ of which were MRSA and $12.5 \%$ were MSSA, Micrococci (17\%), E. coli (15\%), viridans Streptococci (11\%), Diphtheroids (9\%), Klebsiella pneumoniae (5\%) [All of which were ESBL strains] and Enterobacter aerogenes (2\%). 
The majority of isolates in the current work could be described as normal flora that could naturally be present on human skin. This finding coincides with those of other researchers as Brady et al., (2012), Jeske et al., (2007) and Chao Foong et al., (2015) who isolated normal flora from $85 \%, 94.7 \%$ and $95 \%$ of tested mobile phones, respectively.

Although such isolates are considered saprophytic or commensal organisms, yet they can be opportunistic pathogens, particularly in immunocompromised hosts.

Other researchers also isolated CNS at high rates of $43 \%$ to $71.5 \%$ of the tested mobile phones (Lavanya et al., 2016; Amer et al.,2016; Selim and Abaza, 2015; Akinyemi et al., 2009; Kumar et al., 2014; Raghavendra et al., 2014; Karabay et al., 2007 and Bhoonderowa et al., 2014).

MRSA represented $87.5 \%$ of $S$. aureus isolates in the current work, while only 12.5 $\%$ were MSSA. Higher isolation rates were recorded for $S$. aureus in similar studies as that carried out by Selim and Abaza (2015), Tambe et al., (2012) and Raghavendra et al., (2014) who isolated S. aureus from $71.5 \%$, $54 \%$ and $52 \%$ of tested phones, respectively. MRSA was also previously isolated from $40 \%, 53 \%$ and $83 \%$ of mobile phones examined by Rana et al., (2013), Angadi et al., (2014) and Jeske et al., (2007), respectively.

Staphylococci evidently have the highest occurrence on mobile phones. These organisms may probably have found their way into the phone through the skin and from hand to hand. It is a well-known fact that organisms like S.aureus and CNS resist drying and thus can survive and multiply rapidly in the warm environments like cell phones.

\section{Antibiotic sensitivity pattern of bacterial isolates}

As regards the results of the antibiotic sensitivity tests of the isolated organisms in the present study, the highest sensitivity was recorded for ceftazidime $(72.2 \%)$ while the highest resistance was recorded for ampicillin (61.2\%) (Figure 1).

The isolated organisms in this study were resistant to most of the commonly used antibiotics. This may be due to indiscriminate use of multiple antibiotics, intravenous drug abuse, self-medication, and inappropriate use of antibiotics.

The isolation of MRSA and ESBL Klebsiella pneumoniae is a matter of concern. It proves the pathogenic potential of the organisms isolated from mobile phones and highlights the risk of mobile phones as vehicles of transmission of serious multiple drug resistant pathogens.

As the restrictions on the use of mobile phones in the health care institutions by medical personnel are impractical since those mobile devices can be considered as essential instruments for healthcare workers, therefore the emphasis should be put on the prevention of the spread of bacteria through mobile phones by proper hand hygiene and disinfection of mobile phones.

Screening of mobile phones for bacterial contamination on regular basis is recommended specially within health care facilities and laboratories. Using hands free mobile phones during work hours is advised for HCWs and proper infection control practices to prevent the spread of bacteria through mobile phones are recommended to be incorporated in students, curricula and as a part of health education sessions for medical and paramedical personnel. 


\section{Acknowledgment}

I would like to express our deep thanks and sincere appreciation to my dear professors, students and colleagues for their kind efforts performed in this study. I would also like to extend MY hearty thanks and deepest gratitude to the laboratory specialists of the medical laboratory technology department at the Faculty of Allied Medical Sciences, Pharos University.

\section{References}

Akinyemi, K.O., Atapu, A.D., Adetona, O.O., and Coker, A.O. 2009. The potential role of mobile phones in the spread of bacterial infections. J Infect Dev Ctries 3(08):628-632.

Al-Mudares, W.K., Mansour, M.G., and Faeq, M. 2012. Mobile Phone Contamination by Microorganisms in Health Facilities: Comparing Health Care Workers and Patient Visitors in a Post-Operative Pediatric ICU. Inquiries J 4(08): 1.

Amer, I.O., El-jilany, M.E., Fahed, F.M. and Salem, M.A. 2016. Microbial Contamination of Mobile Phones of Healthcare Workers in Teaching Hospitals, West Libya. LJMR 10(1): 140147.

Ananthakrishnan, S. and Gunasekaran, D. 2006. Bacterial Contamination of Mobile Phones of Health Care Workers. Indian J Med Microbiol 55: 165-169.

Ananthakrishnan, S., and Gunasekaran , D. 2009. Etiology and risk factors for early onset neonatal sepsis . Indian J Med Microbiol 27(3): 279.

Angadi, K.M., Misra, R., Gupta, U., Jadhav, S., and Sardar, M. 2014. Study of the role of mobile phones in the transmission of Hospital acquired infections . Med J DY PatilUniv 7(4): 435.

Bauer, A.W., Kirby, W.M.M., Sherris, J.C., and Turck, M. 1966. Antibiotic susceptibility testing by a standardized single disk method. Am J ClinPathol 45(4): 493.
Bhoonderowa, A., Gookool, S., and BiranjiaHurdoyal, S.D. 2014. The importance of mobile phones in the possible transmission of bacterial infections in the community. J Community Health 39(5): 965-967.

Bobat, R., Archary, M., Lawler, M., Mawlana, S., Naidoo, K.L., Maphumulo, S., and Coovadia, Y. 2016. The presence and spectrum of bacteria colonising mobile phones of staff and caregivers in high disease burden paediatric and neonatal wards in an urban teaching hospital in Durban, South Africa. S Afr J Infect Dis 32(1): 9-11.

Brady, R.R., Chitnis, S., Stewart, R.W., Graham, C., Yalamarthi, S., and Morris, K. 2012. NHS connecting for health: healthcare professionals, mobile technology, and infection control. Telemed J E Heath 18(4): 289-291.

Brady, R.R.W., Wasson, A., Stirling, I., McAllister, C., and Damani, N. N. 2006. Is your phone bugged? The incidence of bacteria known to cause nosocomial infection on healthcare workers' mobile phones. J Hosp Infect 62(1): 123-125.

Chaka, T.E., Misgana, G.M., Feye, B.W. and Kassa, R.T. 2016. Bacterial Isolates from Cell Phones and Hands of Health Care Workers: A Cross Sectional Study in Pediatric Wards at Black Lion Hospital, Addis Ababa, Ethiopia. J BacteriolParasitol 7:4.

Chawla, K., Mukhopadhayay, C., Gurung, B., Bhate, P. and Bairy, I. 2009. Bacterial 'Cell' Phones: Do cell phones carry potential pathogens? Online J Health Allied Scs 8(1):8.

Clean link. Study: Public toilet is cleaner than the average cell phone. 2013.

Clinical and Laboratory Standards Institute. 2014. Performance standards for antimicrobial susceptibility testing; Twenty-fourth informational supplement, M100-S24. Wayne, PA: CLSI.

Czapiński, J. and Panek, T. 2011. Objective and subjective quality of life in Poland. SocDiagn 5:64-66. 
Daniel, W.W. 2009. Biostatistics: A foundation for analysis in the health sciences. 9th ed. Hoboken, NJ: Wiley.

Deshkar, S., Ahmed, S., Gedam, D., and Shrikhande, S. 2016. Study of Bacterial Colonization of Mobile Phones and Writing Pens in Tertiary Care Hospital . National Journal of Integrated Research in Medicine, 7(3): 80-82.

Elkholy, M. and Ewees, I. 2010. Mobile (cellular) phones contamination with nosocomial pathogens in intensive care units. Med J Cairo Univ78 (2):1-5.

Foong, Y.C., Green, M., Zargari, A., Siddique, R., Tan, V., Brain, T., and Ogden, K. 2015. Mobile phones as a potential vehicle of infection in a hospital setting. J Occup Environ Hyg 12(10): D232-D235.

Forbes, B.A., Sahm, D.F. and Weissfeld, A.S. 2007. Bailey and Scott's diagnostic microbiology. 12th ed. St-Louis: Mosby.

Fox News. Mobile phone18 times dirtier than toilet handles.

Goel, M., and Goel, A. 2009. Beware! Your phone is 'bugged'mobile phones of dental professionals a potential source of bacterial contamination -A bacteriological study. Indian J Dent Sci 1: 42-7.

Goldblatt, J.G., Krief, I., Klonsky, T., Haller, D., Milloul, V., Sixsmith, D.M., and Potasman, I. 2007. Use of cellular telephones and transmission of pathogens by medical staff in New York and Israel . Infect Control Hosp Epidemiol 28(04): 500-503.

Heyba, M., Ismaiel, M., Alotaibi, A., Mahmoud, M., Baqer, H., Safar, A., and Al-Taiar, A. 2015. Microbiological contamination of mobile phones of clinicians in intensive care units and neonatal care units in public hospitals in Kuwait. BMC Infect Dis 15(1): 434.

Jaya Madhuri, R., Saraswathi, M., Mahitha, G., Bhargavi, M., and Deepika, S. 2015. Bacterial contamination of mobile phones and computers in microbiological laboratories. Eur J BiotechnolBiosci 3(9):51-55.
Jeske, H.C., Tiefenthaler, W., Hohlrieder, M., Hinterberger, G., and Benzer, A. 2007. Bacterial contamination of anaesthetists' hands by personal mobile phone and fixed phone use in the operating theatre Anaesthesia 62(9): 904-906.

Kamis, K., Janevic, M.R., Marinec, N., Jantz, R., Valverde, H., and Piette, J.D. 2015. A study of mobile phone use among patients with noncommunicable diseases in $\mathrm{La}$ Paz, Bolivia: implications for mHealth research and development . Global health 11(1):30.

Karabay, O., Koçoglu, E., and Tahtaci, M. 2007. The role of mobile phones in the spread of bacteria associated with nosocomial infections. J Infect Dev Ctries 1(1): 7273.

Karthiga, K.S. and Muralidharan, M.P. 2016. Screening of mobile phones for the presence of microbes of oral origin. Innovare J Health Sci 4)4): 1-3.

Kumar, B.V., Hobani, Y.H., Abdulhaq, A., Jerah, A.A., Hakami, O.M., Eltigani, M., and Bidwai, A.K. 2014. Prevalence of antibacterial resistant bacterial contaminants from mobile phones of hospital inpatients. Libyan J Med 9(1):14.

Lavanya, J., Rani, N.B., Jais, M., and Upadhya, A.K. 2016. Microbial Contamination of Mobile Phones in a Tertiary Health Care Setting. Int J CurrMicrobiol App Sci 5(9): 508-513.

Mark D., Leonard C., Breen H., Graydon R., O'Gorman C., Kirk S. 2015. Mobile phones in clinical practice: reducing the risk of bacterial contamination. GMS Hygiene and Infection Control, Vol.10, ISSN2196-5226.

Parhizgari N, farajzadehSheikh Aand Sadeghi P.2013.Identification of bacteria isolated from mobile phones of three medical and teaching hospitals administrative and medical staff in Ahvaz. Jentashapir J Health Res; 4(5): 397-403.

Pal, P., Roy, A., Moore, G., Muzslay, M., Lee, E., Alder, S., and Kelly, J. 2013. Keypad mobile phones are associated with a 
significant increased risk of microbial contamination compared to touch screen phones. J Infect Prev 14(2):65-68.

Raghavendra, M.P., Shruthi, K.C., and Shivalingaiah, B. 2014. Bacteriological screening of hands and mobile phones of healthcare workers and its management . Int J Recent Trends Sci Technol 1(10): 92-97.

Ramesh, J., Carter, A.O., Campbell, M.H., Gibbons, N., Powlett, C., Moseley Sr, H., and Carter, T. 2008. Use of mobile phones by medical staff at Queen

Elizabeth Hospital , Barbados: Evidence for both benefit and harm . J Hosp Infect 70(2): 160-165.

Rana, R., Joshi, S., Lakhani, S., Kaur, M., and Patel, P. 2013. Cell phones-homes for microbes. Int J Biol Med Res 4(3): 34033406.

Sadat-Ali M., AL Omran AK., Azam Q., Bukari H., AL Zahrani AJ., Al-Turki RA., et al. 2010. Mobile phones in clinical practice: Reducing the risk of bacterial contamination. Am J Infect Control: 38:404-5?

Selim, H.S. and Abaza, A.F. 2015. Microbial contamination of mobile phones in a health care setting in Alexandria, Egypt. GMS Hyg Infect Control10: Doc03.

Shah, P.D., Trivedi, N.A., Geetha, P.S., Trivedi, M.B., Murawala, S.M., Soni, S.T., and Vegad, M.M. 2013. Mobile Phone can transmit more than just a Call -a Mode of Nosocomial Transmission. Int J Microbiol Res 5(7): 502.

Shakir, I.A., Patel, N.H., Chamberland, R.R., and Kaar, S.G. 2015. Investigation of cell phones as a potential source of bacterial contamination in the operating room . J Bone Joint Surg Am 97(3): 225-231.

Srikanth, P., Rajaram, E., Sudharsanam, S., Lakshmanan, A., Mariappan, U.S.S., and Jagannathan, K. 2010. Mobile phones : emerging threat for infection control . J InfecPrev 11(3): 87-90.

Tagoe, D.N., Gyande, V.K., and Ansah, E.O. 2011. Bacterial contamination of mobile phones: When your mobile phone could transmit more than just a call . Web Med Central Microbiol 2(10): WMC002294.

Tambe, N.N. and Pai, C.A. 2012. Study of microbial flora and MRSA harboured by mobile phones of health care personnel. Int J Recent Trends Sci Technol 4(1):1418.

Tiwari, T., Ankola, A.V., Mishra, H. and Kakkar, M. 2016. Assessment of bacterial contamination in cellular phones of dental professionals working in a dental institution in Belgaum city - a cross sectional study. Med Res Chron 3(3): 266-273.

Ulger, F., Esen, S., Dilek, A., Yanik, K., Gunaydin, M., and Leblebicioglu, $\mathrm{H}$. 2009. Are we aware how contaminated our mobile phones with nosocomial pathogens?

Ann ClinMicrobiolAntimicrob 8(1): 7.

Ustun, C. and Cihangiroglu, M. 2012. Health care workers' mobile phones: a potential cause of microbial cross contamination between hospitals and community. J Occup Environ Hyg 9(9):53842.

\section{How to cite this article:}

Hadir EL-Kady. 2017. Microbial Contamination of Mobile Phones in the Medical Laboratory Technology Department of a Private University in Alexandria, Egypt. Int.J.Curr.Microbiol.App.Sci. 6(6): 200-211. doi: https://doi.org/10.20546/ijcmas.2017.606.024 